\title{
Biomarkers in the Overactive Bladder Syndrome
}

\author{
Célia Duarte Cruz 1,2,3, Tiago Antunes Lopes 2,3,4, \\ Carlos Silva ${ }^{2,3,4}$ and Francisco Cruz $2,3,4, *$ \\ ${ }^{1}$ Department of Experimental Biology, Faculty of Medicine of Porto, \\ 2IBMC - Instituto de Biologia Molecular e Celular, \\ ${ }^{3}$ University of Porto, \\ ${ }^{4}$ Department of Urology, Hospital de S. João, Porto, \\ Portugal
}

\section{Introduction}

Overactive bladder $(\mathrm{OAB})$ is a symptomatic complex affecting both men and women. The overall incidence is above $10 \%$ but may exceed $40 \%$ in the elderly population (Irwin et al., 2006; Irwin et al., 2009; Sexton et al., 2009a). OAB is defined by the International Continence Society (ICS) as a clinical syndrome characterized by urinary urgency, with or without incontinence, usually with frequency and nocturia (Abrams et al., 2002, 2003; Hashim \& Abrams, 2007). Urgency, which is a storage symptom defined as a sudden compelling desire to pass urine difficult to defer, is the hallmark symptom as it is the only one that must be present in order to establish the diagnosis of OAB (Abrams et al., 2002, 2003). Several comorbidities are very common among $\mathrm{OAB}$ patients, including depression, insomnia and fractures (Coyne et al., 2008; Sexton et al., 2009a; Sexton et al., 2009b). The economic costs of $\mathrm{OAB}$, associated with medical consultations, therapy and diminished productivity at work, may reach billions of dollars (Irwin et al., 2009) and will certainly increase with the demographic shift of an ageing population.

The true causes of urgency/OAB remain poorly understood. The difficulty in establishing animal models that accurately represent urgency/OAB still holds. It was originally thought that the origin of $\mathrm{OAB}$ could be ascribed to anomalies in the neuromuscular junction and myocites. More recent data indicate a strong involvement of bladder sensory mechanisms involving the urothelium and suburothelial afferent nerves. In addition, dysfunction of central nervous system centres that control the micturition reflex, including the Periaqueductal Gray (PAG) and pontine micturition centre, has been implicated in the genesis of OAB (Fowler et al., 2008; Drake et al., 2010; Fowler \& Griffiths, 2010).

No cure exists for OAB. Management is initiated by exclusion of confounding diseases and by the introduction of conservative measures, including limiting fluid intake, avoiding caffeinated, acidic and carbonated drinks, weight reduction, smoke avoidance and bladder training. If bothersome $\mathrm{OAB}$ symptoms persist, patients are initiated on antimuscarinic

\footnotetext{
${ }^{*}$ Corresponding Author
} 
therapy, the current mainstay for pharmacological management of OAB (Henderson \& Drake, 2010; Athanasopoulos \& Cruz, 2011). Nevertheless, despite significant improvement, antimuscarinics still produce important side-effects that may lead patients to discontinue treatment (Andersson, 2004; Andersson et al., 2009; Gulur \& Drake, 2010). Moreover, antimuscarinics are contra-indicated for patients with narrow angle, may interfere with cognitive function and aggravate constipation (Gulur \& Drake, 2010), all of which commonly occur in the typical $\mathrm{OAB}$ age group. More recently, the administration of vanilloids and botulinum toxin have been proposed as a possible treatment for OAB but these approaches should be taken with care as they are off-label procedures (Cruz \& Dinis, 2007; da Silva \& Cruz, 2009).

The key symptom in $\mathrm{OAB}$, urgency, may often be confounded with urge to void. Urge is a normal bladder sensation, the intensity of which is proportional to the degree of bladder filling and allows the subject to fully control bladder function. Differentiation between urge and urgency may not always be an easy task for the caregiver or patients, particularly those who are cognitively impaired by age or disease (Michel \& Chapple, 2009a, b). In addition, grading urgency is a difficult task to be accomplished by the clinician, even with the use of standardized questionnaires (Nixon et al., 2005; Starkman \& Dmochowski, 2008). Currently, there is no objective test to diagnose $\mathrm{OAB}$ although several attempts have been made in order to overcome this. Here, we will review recent data proposing new biomarkers for a better characterization of $\mathrm{OAB}$ patients. The value of a biomarker in medicine is considerable and lies in its ability to identify the disease, back diagnostic and therapeutic decisions and establish a valuable prognosis to the condition. In addition, it will positively influence the outcome of the condition. In $\mathrm{OAB}$, investigators have focused on bladder parameters (the presence of detrusor overactivity and the thickness of the bladder wall), serum proteins (the $\mathrm{C}$ reactive protein) and urinary elements (prostaglandins, cytokines and neurotrophins).

\section{Bladder criteria}

\subsection{Detrusor overactivity}

Detrusor overactivity (DO) is the urodynamic observation of involuntary detrusor contractions during the filling phase of cystometry (Abrams et al., 2002).Thus, DO can only be detected by urodynamic assessment, an invasive and expensive test. It has been demonstrated that DO was present in approximately $45 \%$ of OAB-dry and $60 \%$ of OAB-wet patients (Hashim \& Abrams, 2006). As the main symptoms of OAB may suggest the presence of DO, several attempts have been made in order to correlate urgency with DO. However, in a recent study it was shown that reports of urgency sensations during filling cystometry were as likely to occur before or after an episode of DO and approximately one third of the DO events recorded were not associated with urgency (Lowenstein et al., 2009). In addition, DO, may be found in healthy individuals (Heslington \& Hilton, 1996; van Waalwijk van Doorn et al., 1997; Hashim \& Abrams, 2006). In fact, in the study by Hashim and Abrams $36 \%$ of the OAB patients studied (1076) did not present DO and more than $30 \%$ of individuals without OAB had DO (Hashim \& Abrams, 2006). In addition, DO does not predict the response of patients to antimuscarinic treatment (Malone-Lee \& Al-Buheissi, 2009). Hence, the combination of the discomfort felt by patients during an urodynamic evaluation with a low predictive value both for the diagnosis 
and successful outcome of $\mathrm{OAB}$ treatment impedes the routine use of urodynamic assessment for the majority of $\mathrm{OAB}$ patients. In a recent study, investigators tried to identify the presence of involuntary detrusor contractions through near-infrared spectroscopy (NIRS), a noninvasive method (Farag et al., 2011a; Farag et al., 2011b). NIRS is an imaging technique that can be used to monitor haemodynamic events. As the name indicates, it uses light in the nearinfrared area, which is able to penetrate the skin. It is absorbed by oxyhaemoglobin and deoxyhaemoglobin, the levels of which can reflect oxygen consumption. In those studies, investigators were able to demonstrate that detrusor contractions were accompanied by changes in those chromophores (Farag et al., 2011a; Farag et al., 2011b). The overall specificity of NIRS to detect DO was $86 \%$ when measuring oxyhaemoglobin, $80 \%$ for deoxyhaemoglobin and $72 \%$ for the sum of both chromophores. Despite obvious limitations, such as the inclusion of more men than women, results are interesting and deserve further investigation.

\subsection{Bladder wall thickness/Detrusor thickness (BWT/DT)}

In patients with bladder outlet obstruction, the thickness of the total bladder wall or simply the thickness of the detrusor layer was shown in several studies to be significantly increased in OAB patients when compared with healthy volunteers (Hakenberg et al., 2000; Oelke et al., 2006; Oelke et al., 2007). Hence, it was forwarded that BWT/DT could be influenced by the work overload of the bladder wall introduced by DO. Indeed, some authors have reported a trend of increasing DT associated with the severity of urgency as reported by Panayi and coworkers (Panayi et al., 2010). Khullar and co-workers analysed the total BWT via transvaginal ultrasound in a group of female patients with idiopathic DO (Khullar et al., 1996). They found that $58.7 \%$ of all analysed subjects had a mean BWT greater than $5 \mathrm{~mm}$, $94 \%$ of which had DO. Only $1.6 \%$ of subjects had DO with a BWT of $3.5 \mathrm{~mm}$ or less. The authors proposed that the measurement of mean BWT by transvaginal ultrasound, with a cut-off of $5 \mathrm{~mm}$, is a suitable screening method (Khullar et al., 1996). In addition, by determining BWT also with transvaginal ultrasound, Kuhn and co-workers were able to differentiate between women suffering from stress urinary incontinence or bladder outlet obstruction (Kuhn et al., 2011). In OAB patients, DWT was reduced after anti-muscarinic treatment (Liu et al., 2009b; Kuo et al., 2010b). In addition, a positive correlation has been found between the presence of OAB and high BWT/DT(Robinson et al., 2002; Kuo, 2009).

However, the reliability of DT as a marker for DO or OAB is still debatable. BWT/DT are typically measured by ultrasound. One particular problematic issue is the well-known bias associated to the different operators of ultrasound. Another unsolved issue regards the best way to measure BWT/DT. Should the bladder be empty of filled? If filled, at which volume? Should one use an abdominal or transvaginal approach? Which are the costs? In addition, several studies failed to demonstrate significant differences between healthy controls, patients with DO, bladder outlet obstruction or with increased bladder sensation (Blatt et al., 2008). More recently, Liu et al measured the DT in normal controls and patients suffering from OAB or interstitial cystitis (Liu et al., 2009b). They found a wide variation amongst all groups of individuals with a trend of higher BWT/DT in OABwet patients that did not reach statistical significance. In another study, no differences in the BWT/DT were found between OAB patients and individuals with no OAB symptoms (Chung et al., 2010). 
Clearly, the measurement of BWT or DT by ultrasound faces some drawbacks that are not yet overcome. Intra- and inter-operator variability in ultrasound measurements is probably the most important one. The use of different ultrasound probes, as well as in the resolutions of ultrasound-generated images (Kuo, 2009), is another limiting factor to the use of BWT/DT as a biomarker. Although clinically appealing, more studies are necessary before it becomes a tool for daily practice.

\section{Urinary biomarkers}

\subsection{Prostaglandins}

Prostanoids (prostaglandins and thromboxanes) are synthesized by cyclo-oxygenase (COX), present in several tissues including the bladder wall (Khan et al., 1998; Lecci et al., 2000; Azadzoi et al., 2003; Andersson \& Wein, 2004). Two COX isoforms exist. COX-1 is expressed constitutively and participates in normal bladder function whereas COX-2 is activated during cystitis (Lecci et al., 2000; Tramontana et al., 2000). Prostanoid synthesis can be induced by physiological stimuli (for example, detrusor muscle stretching), injuries of the mucosa, nerve stimulation, ATP and inflammatory mediators such as bradykinin and the chemotactic peptide N-formyl-l-methionyl-l-leucyl-l-phenylalanine (Khan et al., 1998; Andersson \& Wein, 2004).

Prostaglandin (PG) $\mathrm{E}_{2}$ is one the most abundant prostanoid in the bladder (Jeremy et al., 1987; Khan et al., 1998). In rats, intravesical administration of $\mathrm{PGE}_{2}$ facilitates micturition, increases basal intravesical pressure and induces bladder hyperactivity (Ishizuka et al., 1995). In the urethra, topical application of $\mathrm{PGE}_{2}$ causes relaxation of the sphincter (Yokoyama et al., 2007). Likewise, intravesical instillation of an inhibitor of the COX-2 enzyme improved bladder function in an animal model of OAB (Jang et al., 2006). This supports a role for this prostanoid during bladder dysfunction and has justified a few inconclusive clinical trials regarding the use of non-steroidal anti-inflammatory drugs in the treatment of $\mathrm{OAB}$. So, expectations were raised when Kim and co-workers found that levels of $\mathrm{PGE}_{2}$ and $\mathrm{PGF}_{2 \alpha}$ were significantly higher in male and female $\mathrm{OAB}$ patients that in healthy controls (Kim et al., 2005; Kim et al., 2006). However, PG concentrations were not corrected for urine concentration. After correction for creatinine values, Liu and co-workers found no significant differences in $\mathrm{PGE}_{2}$ content in patients with $\mathrm{OAB}$ wet, $\mathrm{OAB}$ dry and controls (Liu et al., 2010).

Thus, at this moment the role of urinary PGs, most notably $\mathrm{PGE}_{2}$, as a putative tool for $\mathrm{OAB}$ diagnosis and follow-up is highly debatable. Moreover, the measuring methods rely on labour-intensive and expensive laboratory procedures. In addition, although it is relatively consensual that prostanoids participate in the mechanisms of $\mathrm{OAB}$, it is not known if the recommended $\mathrm{OAB}$ therapies effectively reduce the PGs levels.

\subsection{Urinary cytokines}

The presence of cytokines in the urine has been addressed in various bladder and kidney disorders, including chronic renal disease, interstitial cystitis and vesicoureteral reflux (Ninan et al., 1999; Abdel-Mageed et al., 2003). It has been suggested that OAB may result from an underlying inflammation of the bladder, a hypothesis supported by recent studies 
reporting the presence of histological signs of inflammation in biopsies from $\mathrm{OAB}$ patients (Comperat et al., 2006; Apostolidis et al., 2008). However, confirming the presence of inflammation through biopsies is certainly an invasive procedure not exempt of morbidities. The detection of signs of inflammation in the urine of OAB patients is a more attractive alternative. Tyagi and co-workers have recently collected urine samples from patients and determined the levels of various cytokines, chemokines, growth factors and soluble receptors (Tyagi et al., 2010). Using a luminometry-based assay, they found a significant increase, when compared with controls, in the concentration of various elements, including the monocyte chemotatic protein-1 (MCP-1), the soluble fraction of the CD40 ligand, the macrophage inflammatory protein (MIP-1 $\beta$ ) and interleukins 10, 5 and 12. Another group of researchers also analysed of urine samples from healthy individuals and OAB patients using a proteomic approach (Ghoniem et al., 2011). Interestingly, their results indicate that while the concentration of certain elements increases (such as interleukin 16), the concentration of others decreases (such as interleukin 7). Thus, the actual role of all of these cytokines in OAB is far from being well understood, undermining its utility as biomarkers.

\subsection{Neurotrophins}

Neurotrophins are tissue-derived trophic factors necessary for the embryonic differentiation, survival and maintenance of neuronal cells both in the peripheral and central nervous system (Pezet \& McMahon, 2006). The most well studied neurotrophins are Nerve Growth Factor (NGF) and Brain Derived Neurotrophic Factor (BDNF). They exert their effects via their specific tyrosine kinase (Trk) receptors. NGF binds to TrkA while TrkB is the receptor of BDNF. Both TrkA and TrkB are present in the bladder urothelium and sensory afferents innervating the organ (Qiao \& M.A. Vizzard, 2002; Murray et al., 2004).

\subsubsection{Nerve Growth Factor (NGF)}

NGF has attracted considerable attention in the Urology field. It is accepted that NGF is produced by detrusor muscle cells and by the urothelium (Steers et al., 1991; Steers et al., 1996; Clemow et al., 1997; Clemow et al., 2000; Steers \& Tuttle, 2006). In humans and in rodents, the production of NGF in the lower urinary tract and in the neuronal circuits regulating bladder function is increased in pathological conditions, including cystitis and spinal cord injury (Lowe et al., 1997; Vizzard, 2000; Murray et al., 2004). In addition, exogenous NGF is known to induce bladder overactivity, irrespective of the route of delivery (Lamb et al., 2004; Yoshimura et al., 2006; Zvara \& Vizzard, 2007). Likewise, manipulation of NGF levels improves bladder function and referred pain in rats with cystitis (Hu et al., 2005; Frias et al., 2009).

Recent studies have demonstrated the presence of NGF in the urine of OAB patients (Kim et al., 2005; Kim et al., 2006; Liu \& Kuo, 2008; Liu et al., 2009a, b; Liu et al., 2009c; Jacobs et al., 2010; Liu et al., 2011a). Levels were significantly higher than in healthy individuals and subsided after successful treatment with antimuscarinics (Liu et al., 2009b) or botulinum toxin-A (Liu et al., 2009a), in parallel with a decrease in the USS score. Based on these results, some authors have forwarded the use of NGF as presumed biomarker for OAB (Kuo et al., 2010a). Nevertheless, caution should be advised as most studies have not been placebo controlled which may hamper the interpretation of results. 


\subsubsection{Brain Derived Neurotrophic Factor (BDNF)}

The presence and role of BDNF in the bladder has been scarcely analysed and available results mostly refer to rodent models of bladder dysfunction. Like NGF, BDNF can be synthesized by bladder cells, most notably the urothelium during cystitis (Pinto et al., 2010a) or spinal cord injury (Vizzard, 2000). The expression of TrkB is also abundant in sensory neurons innervating the bladder wall (Qiao \& Vizzard, 2002; Murray et al., 2004). Like in somatic tissue (Kerr et al., 1999; Thompson et al., 1999), BDNF expression in the bladder seems to be under the control of NGF (Schnegelsberg et al., 2010; Girard et al., 2011). BDNF appears to be a key participant in bladder dysfunction in an animal model of cystitis as its sequestration improved both bladder reflex activity and peripheral hypersensitivity (Frias et al., 2009; Pinto et al., 2010a).

In humans, it has been reported that urinary BDNF is elevated in patients suffering from bladder pain syndrome/interstitial cystitis (Pinto et al., 2010b). In OAB, a recent study demonstrated that urinary BDNF was also elevated and significantly decreased after therapeutic intervention (Antunes-Lopes et al., 2011). In addition, the concentration of urinary BDNF was shown to be decreased to normal values after successful OAB treatment (Antunes-Lopes et al., unpublished observations). This may indicate that, like NGF (Kuo et al., 2010a), urinary BDNF may serve as an OAB biomarker. However, further studies are necessary to fully understand the importance of BDNF in $\mathrm{OAB}$, particularly how it can influence the OAB outcome.

\section{Urinary proteomics}

There is a considerable interest in urine as a source of biomarkers for bladder pathologies, $\mathrm{OAB}$ assuming one of the foremost active areas of research. Indeed, urine is one of the most versatile biofluids as it can be easily obtained in large quantities with non-invasive methods and is stable in comparison with other fluids. Several peptides and low molecular weight proteins can be found in urine. When urine is collected for analysis, most of them should have undergone physiological proteolysis as urine may stagnate for hours in the bladder before micturition occurs. This might constitute an advantage as, in contrast with blood, serum or plasma, urinary proteins and peptides will not undergo further degradation upon collection (Kolch et al., 2005; Omenn et al., 2005).

With the advent and improvement of proteomic analysis, increasing attention has been given to the description of the urinary proteome. The number of proteins identified in the human urine is still increasing and is well above 1500 (Adachi et al., 2006; Good et al., 2010). The combination of different analysis methods and sample treatment recently allowed the identification of more than 100000 peptides, 5000 of which were present in more than $40 \%$ of the individuals analysed (Coon et al., 2008). Several methods are currently being used to analyse the urinary proteome, including two dimensional gel electrophoresis mass spectrometry (2DE-MS), liquid chromatography MS (LC-MS), surface-enhanced laser desorption/ionization (SELDI-TOF) and capillary electrophoresis MS (CE-MS). If interested in more details and the specific advantages and disadvantages of each method, the readers are advised to seek that information elsewhere (Decramer et al., 2008).

With the recent advances in urinary proteomics, researchers are becoming more aware of problems arising during storage and preparation of samples. One important issue is the 
stability of urine samples. Studies show that sequential freeze/thaw cycles may affect the concentration of certain proteins. Schaub and co-workers showed that there were no significant differences in the protein profile between samples analysed before freezing and after 1 to 4 freeze-thaw cycles (Schaub et al., 2004). These results have been confirmed in subsequent studies by non-related groups (Fiedler et al., 2007; Thongboonkerd, 2007). No data is available regarding the proteomic analysis of the urine of $\mathrm{OAB}$ patients.

\section{Serum biomarkers}

\subsection{C- reactive protein (CRP)}

CRP is a highly conserved plasma protein. It was identified in the 1930's in the sera of patients in the acute phase of pneumonia by Tillet and co-workers (Tillett \& Francis, 1930; Black et al., 2004). Further studies demonstrated that the concentration of CRP in plasma is significantly increased during inflammatory states, a characteristic that has often been used for diagnostic purposes. In what concerns the urinary tract, plasma CRP has been used to monitor the progression of bladder cancer (Hilmy et al., 2006; Gakis et al., 2011a; Gakis et al., 2011b). As far as we are aware, CRP has been addressed in OAB only in a recent pilot study. Chung and co-workers observed higher levels of serum CRP in OAB patients than in controls, particularly in the group of OAB wet patients (Chung et al., 2011). Both urinary CRP and the amount of CRP mRNA present in the bladder wall were very low, indicating that the serum is the body fluid of choice to measure this protein. However, one should be aware that serum CRP would most likely reflect the presence of any inflammatory condition (Black et al., 2004), making its use as a putative biomarker in OAB is very modest.

\subsection{Serum NGF}

Like in urine, the presence of NGF in the serum of OAB patients has also been investigated (Liu et al., 2011b). The authors found a positive correlation between urinary and serum NGF contents. Interestingly, serum NGF remained elevated in OAB patients not responding to antimuscarinic treatment, suggesting that increased circulating NGF may be a factor in refractory $\mathrm{OAB}$. This is, however, the only available study regarding serum NGF levels in $\mathrm{OAB}$. It is presently not clear if the high content of NGF in the serum was strictly associated with $\mathrm{OAB}$ or dependent on associated comorbidities (hypertension, diabetes, coronary arterial disease, etc.) (Brown et al., 2000). More studies are needed in order to fully understand the relevance of serum NGF in OAB.

\section{Conclusion}

Clinicians and researchers are still far from having a tool to efficiently detect and monitor OAB. Several attempts have been made to identify specific bladder parameters, serum and urinary proteins that could fulfil such purpose. In all cases, researchers have come across issues. Due to several problems, the real clinical relevance of each proposed biomarker is still very much unclear, most of the publications reflecting more the willingness of the investigators rather than the true scientific value of findings. More studies are clearly necessary. In the near future, it is likely that some of these issues are overcome, as researchers are increasingly aware of the need to standardize methodologies and are already proposing basic protocols that could be easily adopted by most laboratories. Multicentre 
collaborative studies are also necessary to increase the size of the cohorts analysed and decrease the obvious bias of single centre findings. Hopefully, this area of research will arrive to a positive destiny with a beneficial impact on the diagnosis and outcome of OAB patients.

\section{Acknowledgment}

This work has been funded by INCOMB - FP7 Health project no. 223234.

\section{References}

Abdel-Mageed, A.B.; Bajwa, A.; Shenassa, B.B.; Human, L. \& Ghoniem, G.M. (2003). NFkappaB-dependent gene expression of proinflammatory cytokines in T24 cells: possible role in interstitial cystitis. Urol Res, Vol.31, No.5, (Oct 2003), pp. 300-305, ISSN 0300-5623 (Print) 0300-5623 (Linking)

Abrams, P.; Cardozo, L.; Fall, M.; Griffiths, D.; Rosier, P.; Ulmsten, U.; van Kerrebroeck, P.; Victor, A. \& Wein, A. (2002). The standardisation of terminology of lower urinary tract function: report from the Standardisation Sub-committee of the International Continence Society. Neurourol Urodyn, Vol.21, No.2, (2002), pp. 167-178, ISSN 07332467 (Print), 0733-2467 (Linking)

Abrams, P.; Cardozo, L.; Fall, M.; Griffiths, D.; Rosier, P.; Ulmsten, U.; Van Kerrebroeck, P.; Victor, A. \& Wein, A. (2003). The standardisation of terminology in lower urinary tract function: report from the standardisation sub-committee of the International Continence Society. Urology, Vol.61, No.1, (Jan 2003), pp. 37-49, ISSN 1527-9995 (Electronic) 0090-4295 (Linking)

Adachi, J.; Kumar, C.; Zhang, Y.; Olsen, J.V. \& Mann, M. (2006). The human urinary proteome contains more than 1500 proteins, including a large proportion of membrane proteins. Genome Biol, Vol.7, No.9, (2006), pp. R80, ISSN 1465-6914 (Electronic) 1465-6906 (Linking)

Andersson, K.E. \& Wein, A.J. (2004). Pharmacology of the lower urinary tract: basis for current and future treatments of urinary incontinence. Pharmacol Rev, Vol.56, No.4, (Dec 2004), pp. 581-631, ISSN 0031-6997 (Print) 0031-6997 (Linking)

Andersson, K.E.; Chapple, C.R.; Cardozo, L.; Cruz, F.; Hashim, H.; Michel, M.C.; Tannenbaum, C. \& Wein, A.J. (2009). Pharmacological treatment of overactive bladder: report from the International Consultation on Incontinence. Curr Opin Urol, Vol.19, No.4, (Jul 2009), pp. 380-394, ISSN 1473-6586 (Electronic) 0963-0643 (Linking)

Andersson, K.E.S., A. (2004) Pharmacology of the lower urinary tract., Textbook of the neurogenic bladder (Corcos JS, E, ed), pp 57-72. London: Dunitz, M.

Antunes-Lopes, T.; Pinto, R.; Carvalho-Barros, S.; Diniz, P.; Martins-Silva, C.; Duarte-Cruz, C. \& Cruz, F. (2011). Urinary levels of Brain Derived Neurotrophic Factor (BDNF) in women with overactive bladder (OAB) syndrome correlate with the severity of symptoms. European Urology Supplements, Vol.10, No.2, (Mar 2011), pp. 277-278, ISSN 1569-9056

Apostolidis, A.; Jacques, T.S.; Freeman, A. et al. (2008). Histological changes in the urothelium and suburothelium of human overactive bladder following intradetrusor injections of botulinum neurotoxin type A for the treatment of 
neurogenic or idiopathic detrusor overactivity. Eur Urol, Vol.53, No.6, (Jun 2008), pp. 1245-1253, ISSN 0302-2838 (Print) 0302-2838 (Linking)

Athanasopoulos, A. \& Cruz, F. (2011). The medical treatment of overactive bladder, including current and future treatments. Expert Opin Pharmacother, Vol.12, No.7, (May 2011), pp. 1041-1055, ISSN 1744-7666 (Electronic) 1465-6566 (Linking)

Azadzoi, K.M.; Shinde, V.M.; Tarcan, T.; Kozlowski, R. \& Siroky, M.B. (2003). Increased leukotriene and prostaglandin release, and overactivity in the chronically ischemic bladder. J Urol, Vol.169, No.5, (May 2003), pp. 1885-1891, ISSN 0022-5347 (Print) 0022-5347 (Linking)

Black, S.; Kushner, I. \& Samols, D. (2004). C-reactive Protein. J Biol Chem, Vol.279, No.47, (Nov 19 2004), pp. 48487-48490, ISSN 0021-9258 (Print) 0021-9258 (Linking)

Blatt, A.H.; Titus, J. \& Chan, L. (2008). Ultrasound measurement of bladder wall thickness in the assessment of voiding dysfunction. J Urol, Vol.179, No.6, (Jun 2008), pp. 22752278; discussion 2278-2279, ISSN 1527-3792 (Electronic) 0022-5347 (Linking)

Brown, J.S.; McGhan, W.F. \& Chokroverty, S. (2000). Comorbidities associated with overactive bladder. Am J Manag Care, Vol.6, No.11 Suppl, (Jul 2000), pp. S574-579, ISSN 1088-0224 (Print) 1088-0224 (Linking)

Chung, S.D.; Chiu, B.; Kuo, H.C.; Chuang, Y.C.; Wang, C.C.; Guan, Z. \& Chancellor, M.B. (2010). Transabdominal ultrasonography of detrusor wall thickness in women with overactive bladder. BJU Int, Vol.105, No.5, (2010 Mar 2010), pp. 668-672, ISSN 1464410X (Electronic) 1464-4096 (Linking)

Chung, S.D.; Liu, H.T.; Lin, H. \& Kuo, H.C. (2011). Elevation of serum c-reactive protein in patients with $\mathrm{OAB}$ and IC/BPS implies chronic inflammation in the urinary bladder. Neurourol Urodyn, Vol.30, No.3, (Mar 2011), pp. 417-420, ISSN 1520-6777 (Electronic) 0733-2467 (Linking)

Clemow, D.B.; McCarty, R.; Steers, W.D. \& Tuttle, J.B. (1997). Efferent and afferent neuronal hypertrophy associated with micturition pathways in spontaneously hypertensive rats. Neurourol Urodyn, Vol.16, No.4, (1997), pp. 293-303, ISSN 0733-2467 (Print) 0733-2467 (Linking)

Clemow, D.B.; Steers, W.D. \& Tuttle, J.B. (2000). Stretch-activated signaling of nerve growth factor secretion in bladder and vascular smooth muscle cells from hypertensive and hyperactive rats. J Cell Physiol, Vol.183, No.3, (Jun 2000), pp. 289-300, ISSN 00219541 (Print) 0021-9541 (Linking)

Comperat, E.; Reitz, A.; Delcourt, A.; Capron, F.; Denys, P. \& Chartier-Kastler, E. (2006). Histologic features in the urinary bladder wall affected from neurogenic overactivity--a comparison of inflammation, oedema and fibrosis with and without injection of botulinum toxin type A. Eur Urol, Vol.50, No.5, (Nov 2006), pp. 10581064, ISSN 0302-2838 (Print) 0302-2838 (Linking)

Coon, J.J.; Zurbig, P.; Dakna, M. et al. (2008). CE-MS analysis of the human urinary proteome for biomarker discovery and disease diagnostics. Proteomics Clin Appl, Vol.2, No.7-8, (Jul 10 2008), pp. 964, ISSN 1862-8354 (Electronic) 1862-8346 (Linking)

Coyne, K.S.; Sexton, C.C.; Irwin, D.E.; Kopp, Z.S.; Kelleher, C.J. \& Milsom, I. (2008). The impact of overactive bladder, incontinence and other lower urinary tract symptoms on quality of life, work productivity, sexuality and emotional well-being in men and women: results from the EPIC study. BJU Int, Vol.101, No.11, (Jun 2008), pp. 1388-1395, ISSN 1464-410X (Electronic) 1464-4096 (Linking) 
Cruz, F. \& Dinis, P. (2007). Resiniferatoxin and botulinum toxin type A for treatment of lower urinary tract symptoms. Neurourol Urodyn, Vol.26, No.6 Suppl, (Oct 2007), pp. 920-927, ISSN 0733-2467 (Print) 0733-2467 (Linking)

da Silva, C.M. \& Cruz, F. (2009). Has botulinum toxin therapy come of age: what do we know, what do we need to know, and should we use it? Curr Opin Urol, Vol.19, No.4, (Jul 2009), pp. 347-352, ISSN 1473-6586 (Electronic) 0963-0643 (Linking)

Decramer, S.; Gonzalez de Peredo, A.; Breuil, B.; Mischak, H.; Monsarrat, B.; Bascands, J.L. \& Schanstra, J.P. (2008). Urine in clinical proteomics. Mol Cell Proteomics, Vol.7, No.10, (Oct 2008), pp. 1850-1862, ISSN 1535-9484 (Electronic) 1535-9476 (Linking)

Drake, M.J.; Fowler, C.J.; Griffiths, D.; Mayer, E.; Paton, J.F. \& Birder, L. (2010). Neural control of the lower urinary and gastrointestinal tracts: supraspinal CNS mechanisms. Neurourol Urodyn, Vol.29, No.1, (2010), pp. 119-127, ISSN 1520-6777 (Electronic) 0733-2467 (Linking)

Farag, F.F.; Martens, F.M.; D'Hauwers, K.W.; Feitz, W.F. \& Heesakkers, J.P. (2011a). Nearinfrared spectroscopy: a novel, noninvasive, diagnostic method for detrusor overactivity in patients with overactive bladder symptoms--a preliminary and experimental study. Eur Urol, Vol.59, No.5, (May 2011a), pp. 757-762, ISSN 18737560 (Electronic) 0302-2838 (Linking)

Farag, F.F.; Martens, F.M.; Feitz, W.F. \& Heesakkers, J.P. (2011b). Feasibility of Noninvasive Near-Infrared Spectroscopy to Diagnose Detrusor Overactivity. Urol Int, (Aug 24 2011b), pp. ISSN 1423-0399 (Electronic) 0042-1138 (Linking)

Fiedler, G.M.; Baumann, S.; Leichtle, A.; Oltmann, A.; Kase, J.; Thiery, J. \& Ceglarek, U. (2007). Standardized peptidome profiling of human urine by magnetic bead separation and matrix-assisted laser desorption/ionization time-of-flight mass spectrometry. Clin Chem, Vol.53, No.3, (Mar 2007), pp. 421-428, ISSN 0009-9147 (Print) 0009-9147 (Linking)

Fowler, C.J.; Griffiths, D. \& de Groat, W.C. (2008). The neural control of micturition. Nat Rev Neurosci, Vol.9, No.6, (Jun 2008), pp. 453-466, ISSN 1471-0048 (Electronic) 1471-003X (Linking)

Fowler, C.J. \& Griffiths, D.J. (2010). A decade of functional brain imaging applied to bladder control. Neurourol Urodyn, Vol.29, No.1, (2010), pp. 49-55, ISSN 1520-6777 (Electronic) 0733-2467 (Linking)

Frias, B.; Charrua, A.; Pinto, R.; Allen, S.; Dawbarn, D.; Cruz, F. \& Cruz, C.D. (2009). Intrathecal blockade of Trk receptors and neurotrophin sequestration reduces pain and urinary frequency in an animal model of chronic bladder inflammation. Neurourology and Urodynamics, Vol.28, No.7, (2009 2009), pp. 708-708, ISSN 07332467

Gakis, G.; Todenhoefer, T.; Renninger, M.; Schilling, D.; Sievert, K.D.; Schwentner, C. \& Stenzl, A. (2011a). Development of a new outcome prediction model in carcinoma invading the bladder based on preoperative serum C-reactive protein and standard pathological risk factors: the TNR-C score. BJU Int, (Apr 20 2011a), pp. ISSN 1464410X (Electronic) 1464-4096 (Linking)

Gakis, G.; Todenhofer, T. \& Stenzl, A. (2011b). The prognostic value of hematological and systemic inflammatory disorders in invasive bladder cancer. Curr Opin Urol, Vol.21, No.5, (Sep 2011b), pp. 428-433, ISSN 1473-6586 (Electronic) 0963-0643 (Linking) 
Ghoniem, G.; Faruqui, N.; Elmissiry, M.; Mahdy, A.; Abdelwahab, H.; Oommen, M. \& Abdel-Mageed, A.B. (2011). Differential profile analysis of urinary cytokines in patients with overactive bladder. Int Urogynecol J, Vol.22, No.8, (Aug 2011), pp. $953-$ 961, ISSN 1433-3023 (Electronic) 0937-3462 (Linking)

Girard, B.M.; Malley, S.E. \& Vizzard, M.A. (2011). Neurotrophin/receptor expression in urinary bladder of mice with overexpression of NGF in urothelium. Am J Physiol Renal Physiol, Vol.300, No.2, (Feb 2011), pp. F345-355, ISSN 1522-1466 (Electronic) 1522-1466 (Linking)

Good, D.M.; Zurbig, P.; Argiles, A. et al. (2010). Naturally occurring human urinary peptides for use in diagnosis of chronic kidney disease. Mol Cell Proteomics, Vol.9, No.11, (Nov 2010), pp. 2424-2437, ISSN 1535-9484 (Electronic) 1535-9476 (Linking)

Gulur, D.M. \& Drake, M.J. (2010). Management of overactive bladder. Nat Rev Urol, Vol.7, No.10, (Oct 2010), pp. 572-582, ISSN 1759-4820 (Electronic) 1759-4812 (Linking)

Hakenberg, O.W.; Linne, C.; Manseck, A. \& Wirth, M.P. (2000). Bladder wall thickness in normal adults and men with mild lower urinary tract symptoms and benign prostatic enlargement. Neurourol Urodyn, Vol.19, No.5, (2000), pp. 585-593, ISSN 0733-2467 (Print) 0733-2467 (Linking)

Hashim, H. \& Abrams, P. (2006). Is the bladder a reliable witness for predicting detrusor overactivity? J Urol, Vol.175, No.1, (Jan 2006), pp. 191-194; discussion 194-195, ISSN 0022-5347 (Print) 0022-5347 (Linking)

Hashim, H. \& Abrams, P. (2007). Overactive bladder: an update. Curr Opin Urol, Vol.17, No.4, (Jul 2007), pp. 231-236, ISSN 0963-0643 (Print) 0963-0643 (Linking)

Henderson, E. \& Drake, M. (2010). Overactive bladder. Maturitas, Vol.66, No.3, (Jul 2010), pp. 257-262, ISSN 1873-4111 (Electronic) 0378-5122 (Linking)

Heslington, K. \& Hilton, P. (1996). Ambulatory monitoring and conventional cystometry in asymptomatic female volunteers. Br J Obstet Gynaecol, Vol.103, No.5, (May 1996), pp. 434-441, ISSN 0306-5456 (Print) 0306-5456 (Linking)

Hilmy, M.; Campbell, R.; Bartlett, J.M.; McNicol, A.M.; Underwood, M.A. \& McMillan, D.C. (2006). The relationship between the systemic inflammatory response, tumour proliferative activity, T-lymphocytic infiltration and COX-2 expression and survival in patients with transitional cell carcinoma of the urinary bladder. $\mathrm{Br} J$ Cancer, Vol.95, No.9, (Nov 6 2006), pp. 1234-1238, ISSN 0007-0920 (Print) 0007-0920 (Linking)

Hu, V.Y.; Zvara, P.; Dattilio, A.; Redman, T.L.; Allen, S.J.; Dawbarn, D.; Stroemer, R.P. \& Vizzard, M.A. (2005). Decrease in bladder overactivity with REN1820 in rats with cyclophosphamide induced cystitis. J Urol, Vol.173, No.3, (Mar 2005), pp. 10161021, ISSN 0022-5347 (Print) 0022-5347 (Linking)

Irwin, D.E.; Milsom, I.; Hunskaar, S. et al. (2006). Population-based survey of urinary incontinence, overactive bladder, and other lower urinary tract symptoms in five countries: results of the EPIC study. Eur Urol, Vol.50, No.6, (Dec 2006), pp. 13061314; discussion 1314-1305, ISSN 0302-2838 (Print) 0302-2838 (Linking)

Irwin, D.E.; Milsom, I.; Kopp, Z.; Abrams, P.; Artibani, W. \& Herschorn, S. (2009). Prevalence, severity, and symptom bother of lower urinary tract symptoms among men in the EPIC study: impact of overactive bladder. Eur Urol, Vol.56, No.1, (Jul 2009), pp. 14-20, ISSN 1873-7560 (Electronic) 0302-2838 (Linking) 
Ishizuka, O; Mattiasson, A. \& Andersson, K.E. (1995). Prostaglandin E2-induced bladder hyperactivity in normal, conscious rats: involvement of tachykinins? J Urol, Vol.153, No.6, (Jun 1995), pp. 2034-2038, ISSN 0022-5347 (Print) 0022-5347 (Linking)

Jacobs, B.L.; Smaldone, M.C.; Tyagi, V.; Philips, B.J.; Jackman, S.V.; Leng, W.W. \& Tyagi, P. (2010). Increased nerve growth factor in neurogenic overactive bladder and interstitial cystitis patients. Can J Urol, Vol.17, No.1, (Feb 2010), pp. 4989-4994, ISSN 1195-9479 (Print) 1195-9479 (Linking)

Jang, J.; Park, E.Y.; Seo, S.I.; Hwang, T.K. \& Kim, J.C. (2006). Effects of intravesical instillation of cyclooxygenase-2 inhibitor on the expression of inducible nitric oxide synthase and nerve growth factor in cyclophosphamide-induced overactive bladder. BJU Int, Vol.98, No.2, (Aug 2006), pp. 435-439, ISSN 1464-4096 (Print) 14644096 (Linking)

Jeremy, J.Y.; Tsang, V.; Mikhailidis, D.P.; Rogers, H.; Morgan, R.J. \& Dandona, P. (1987). Eicosanoid synthesis by human urinary bladder mucosa: pathological implications. Br J Urol, Vol.59, No.1, (Jan 1987), pp. 36-39, ISSN 0007-1331 (Print) 0007-1331 (Linking)

Kerr, B.J.; Bradbury, E.J.; Bennett, D.L.; Trivedi, P.M.; Dassan, P.; French, J.; Shelton, D.B.; McMahon, S.B. \& Thompson, S.W. (1999). Brain-derived neurotrophic factor modulates nociceptive sensory inputs and NMDA-evoked responses in the rat spinal cord. J Neurosci, Vol.19, No.12, (Jun 15 1999), pp. 5138-5148, ISSN 1529-2401 (Electronic) 0270-6474 (Linking)

Khan, M.A.; Thompson, C.S.; Mumtaz, F.H.; Jeremy, J.Y.; Morgan, R.J. \& Mikhailidis, D.P. (1998). Role of prostaglandins in the urinary bladder: an update. Prostaglandins Leukot Essent Fatty Acids, Vol.59, No.6, (Dec 1998), pp. 415-422, ISSN 0952-3278 (Print) 0952-3278 (Linking)

Khullar, V.; Cardozo, L.D.; Salvatore, S. \& Hill, S. (1996). Ultrasound: a noninvasive screening test for detrusor instability. Br J Obstet Gynaecol, Vol.103, No.9, (Sep 1996), pp. 904-908, ISSN 0306-5456 (Print) 0306-5456 (Linking)

Kim, J.C.; Park, E.Y.; Hong, S.H.; Seo, S.I.; Park, Y.H. \& Hwang, T.K. (2005). Changes of urinary nerve growth factor and prostaglandins in male patients with overactive bladder symptom. Int J Urol, Vol.12, No.10, (Oct 2005), pp. 875-880, ISSN 0919-8172 (Print) 0919-8172 (Linking)

Kim, J.C.; Park, E.Y.; Seo, S.I.; Park, Y.H. \& Hwang, T.K. (2006). Nerve growth factor and prostaglandins in the urine of female patients with overactive bladder. J Urol, Vol.175, No.5, (May 2006), pp. 1773-1776; discussion 1776, ISSN 0022-5347 (Print) 0022-5347 (Linking)

Kolch, W.; Neususs, C.; Pelzing, M. \& Mischak, H. (2005). Capillary electrophoresis-mass spectrometry as a powerful tool in clinical diagnosis and biomarker discovery. Mass Spectrom Rev, Vol.24, No.6, (Nov-Dec 2005), pp. 959-977, ISSN 0277-7037 (Print) 0277-7037 (Linking)

Kuhn, A.; Genoud, S.; Robinson, D.; Herrmann, G.; Gunthert, A.; Brandner, S. \& Raio, L. (2011). Sonographic transvaginal bladder wall thickness: does the measurement discriminate between urodynamic diagnoses? Neurourol Urodyn, Vol.30, No.3, (Mar 2011), pp. 325-328, ISSN 1520-6777 (Electronic) 0733-2467 (Linking)

Kuo, H.C. (2009). Measurement of detrusor wall thickness in women with overactive bladder by transvaginal and transabdominal sonography. Int Urogynecol J Pelvic 
Floor Dysfunct, Vol.20, No.11, (Nov 2009), pp. 1293-1299, ISSN 1433-3023 (Electronic) 0937-3462 (Linking)

Kuo, H.C.; Liu, H.T. \& Chancellor, M.B. (2010a). Can urinary nerve growth factor be a biomarker for overactive bladder? Rev Urol, Vol.12, No.2-3, (Spring 2010a), pp. e6977, ISSN 1523-6161 (Print) 1523-6161 (Linking)

Kuo, H.C.; Liu, H.T. \& Chancellor, M.B. (2010b). Urinary nerve growth factor is a better biomarker than detrusor wall thickness for the assessment of overactive bladder with incontinence. Neurourol Urodyn, Vol.29, No.3, (2010 Mar 2010b), pp. 482-487, ISSN 1520-6777 (Electronic) 0733-2467 (Linking)

Lamb, K.; Gebhart, G.F. \& Bielefeldt, K. (2004). Increased nerve growth factor expression triggers bladder overactivity. J Pain, Vol.5, No.3, (Apr 2004), pp. 150-156, ISSN 1526-5900 (Print) 1526-5900 (Linking)

Lecci, A.; Birder, L.A.; Meini, S.; Catalioto, R.M.; Tramontana, M.; Giuliani, S.; Criscuoli, M. \& Maggi, C.A. (2000). Pharmacological evaluation of the role of cyclooxygenase isoenzymes on the micturition reflex following experimental cystitis in rats. $\mathrm{Br} J$ Pharmacol, Vol.130, No.2, (May 2000), pp. 331-338, ISSN 0007-1188 (Print) 0007-1188 (Linking)

Liu, H.T. \& Kuo, H.C. (2008). Urinary nerve growth factor level could be a potential biomarker for diagnosis of overactive bladder. J Urol, Vol.179, No.6, (Jun 2008), pp. 2270-2274, ISSN 1527-3792 (Electronic) 0022-5347 (Linking)

Liu, H.T.; Chancellor, M.B. \& Kuo, H.C. (2009a). Urinary nerve growth factor levels are elevated in patients with detrusor overactivity and decreased in responders to detrusor botulinum toxin-A injection. Eur Urol, Vol.56, No.4, (Oct 2009a), pp. 700706, ISSN 1873-7560 (Electronic) 0302-2838 (Linking)

Liu, H.T.; Chancellor, M.B. \& Kuo, H.C. (2009b). Decrease of urinary nerve growth factor levels after antimuscarinic therapy in patients with overactive bladder. BJU Int, Vol.103, No.12, (Jun 2009b), pp. 1668-1672, ISSN 1464-410X (Electronic) 1464-4096 (Linking)

Liu, H.T.; Liu, A.B.; Chancellor, M.B. \& Kuo, H.C. (2009c). Urinary nerve growth factor level is correlated with the severity of neurological impairment in patients with cerebrovascular accident. BJU Int, Vol.104, No.8, (Oct 2009c), pp. 1158-1162, ISSN 1464-410X (Electronic) 1464-4096 (Linking)

Liu, H.T.; Tyagi, P.; Chancellor, M.B. \& Kuo, H.C. (2010). Urinary nerve growth factor but not prostaglandin E2 increases in patients with interstitial cystitis/bladder pain syndrome and detrusor overactivity. BJU Int, Vol.106, No.11, (Dec 2010), pp. 16811685, ISSN 1464-410X (Electronic) 1464-4096 (Linking)

Liu, H.T.; Chen, C.Y. \& Kuo, H.C. (2011a). Urinary nerve growth factor in women with overactive bladder syndrome. BJU Int, Vol.107, No.5, (Mar 2011a), pp. 799-803, ISSN 1464-410X (Electronic) 1464-4096 (Linking)

Liu, H.T.; Lin, H. \& Kuo, H.C. (2011b). Increased serum nerve growth factor levels in patients with overactive bladder syndrome refractory to antimuscarinic therapy. Neurourol Urodyn, (Aug 8 2011b), pp. ISSN 1520-6777 (Electronic) 0733-2467 (Linking)

Lowe, E.M.; Anand, P.; Terenghi, G.; Williams-Chestnut, R.E.; Sinicropi, D.V. \& Osborne, J.L. (1997). Increased nerve growth factor levels in the urinary bladder of women 
with idiopathic sensory urgency and interstitial cystitis. Br J Urol, Vol.79, No.4, (Apr 1997), pp. 572-577, ISSN 0007-1331 (Print) 0007-1331 (Linking)

Lowenstein, L.; Pham, T.; Abbasy, S. et al. (2009). Observations relating to urinary sensation during detrusor overactivity. Neurourol Urodyn, Vol.28, No.6, (2009), pp. 497-500, ISSN 1520-6777 (Electronic) 0733-2467 (Linking)

Malone-Lee, J.G. \& Al-Buheissi, S. (2009). Does urodynamic verification of overactive bladder determine treatment success? Results from a randomized placebocontrolled study. BJU Int, Vol.103, No.7, (Apr 2009), pp. 931-937, ISSN 1464-410X (Electronic) 1464-4096 (Linking)

Michel, M.C. \& Chapple, C.R. (2009a). Basic mechanisms of urgency: roles and benefits of pharmacotherapy. World J Urol, Vol.27, No.6, (Dec 2009a), pp. 705-709, ISSN 14338726 (Electronic) 0724-4983 (Linking)

Michel, M.C. \& Chapple, C.R. (2009b). Basic mechanisms of urgency: preclinical and clinical evidence. Eur Urol, Vol.56, No.2, (Aug 2009b), pp. 298-307, ISSN 1873-7560 (Electronic) 0302-2838 (Linking)

Murray, E.; Malley, S.E.; Qiao, L.Y.; Hu, V.Y. \& Vizzard, M.A. (2004). Cyclophosphamide induced cystitis alters neurotrophin and receptor tyrosine kinase expression in pelvic ganglia and bladder. J Urol, Vol.172, No.6 Pt 1, (Dec 2004), pp. 2434-2439, ISSN 0022-5347 (Print) 0022-5347 (Linking)

Ninan, G.K.; Jutley, R.S. \& Eremin, O. (1999). Urinary cytokines as markers of reflux nephropathy. J Urol, Vol.162, No.5, (Nov 1999), pp. 1739-1742, ISSN 0022-5347 (Print) 0022-5347 (Linking)

Nixon, A.; Colman, S.; Sabounjian, L.; Sandage, B.; Schwiderski, U.E.; Staskin, D.R. \& Zinner, N. (2005). A validated patient reported measure of urinary urgency severity in overactive bladder for use in clinical trials. J Urol, Vol.174, No.2, (Aug 2005), pp. 604-607, ISSN 0022-5347 (Print) 0022-5347 (Linking)

Oelke, M.; Hofner, K.; Jonas, U.; Ubbink, D.; de la Rosette, J. \& Wijkstra, H. (2006). Ultrasound measurement of detrusor wall thickness in healthy adults. Neurourol Urodyn, Vol.25, No.4, (2006), pp. 308-317; discussion 318, ISSN 0733-2467 (Print) 0733-2467 (Linking)

Oelke, M.; Hofner, K.; Jonas, U.; de la Rosette, J.J.; Ubbink, D.T. \& Wijkstra, H. (2007). Diagnostic accuracy of noninvasive tests to evaluate bladder outlet obstruction in men: detrusor wall thickness, uroflowmetry, postvoid residual urine, and prostate volume. Eur Urol, Vol.52, No.3, (Sep 2007), pp. 827-834, ISSN 0302-2838 (Print) 0302-2838 (Linking)

Omenn, G.S.; States, D.J.; Adamski, M. et al. (2005). Overview of the HUPO Plasma Proteome Project: results from the pilot phase with 35 collaborating laboratories and multiple analytical groups, generating a core dataset of 3020 proteins and a publicly-available database. Proteomics, Vol.5, No.13, (Aug 2005), pp. 3226-3245, ISSN 1615-9853 (Print) 1615-9853 (Linking)

Panayi, D.C.; Tekkis, P.; Fernando, R.; Hendricken, C. \& Khullar, V. (2010). Ultrasound measurement of bladder wall thickness is associated with the overactive bladder syndrome. Neurourol Urodyn, Vol.29, No.7, (Sep 2010), pp. 1295-1298, ISSN 15206777 (Electronic) 0733-2467 (Linking) 
Pezet, S. \& McMahon, S.B. (2006). Neurotrophins: mediators and modulators of pain. Annu Rev Neurosci, Vol.29, (2006), pp. 507-538, ISSN 0147-006X (Print) 0147-006X (Linking)

Pinto, R.; Frias, B.; Allen, S.; Dawbarn, D.; McMahon, S.B.; Cruz, F. \& Cruz, C.D. (2010a). Sequestration of brain derived nerve factor by intravenous delivery of TrkB-Ig2 reduces bladder overactivity and noxious input in animals with chronic cystitis. Neuroscience, Vol.166, No.3, (Mar 31 2010a), pp. 907-916, ISSN 1873-7544 (Electronic) 0306-4522 (Linking)

Pinto, R.; Lopes, T.; Frias, B.; Silva, A.; Silva, J.A.; Silva, C.M.; Cruz, C.; Cruz, F. \& Dinis, P. (2010b). Trigonal injection of botulinum toxin A in patients with refractory bladder pain syndrome/interstitial cystitis. Eur Urol, Vol.58, No.3, (Sep 2010b), pp. 360-365, ISSN 1873-7560 (Electronic) 0302-2838 (Linking)

Qiao, L. \& Vizzard, M.A. (2002). Up-regulation of tyrosine kinase (Trka, Trkb) receptor expression and phosphorylation in lumbosacral dorsal root ganglia after chronic spinal cord (T8-T10) injury. J Comp Neurol, Vol.449, No.3, (Jul 29 2002), pp. 217-230, ISSN 0021-9967 (Print) 0021-9967 (Linking)

Qiao, L.Y. \& Vizzard, M.A. (2002). Cystitis-induced upregulation of tyrosine kinase (TrkA, TrkB) receptor expression and phosphorylation in rat micturition pathways. J Comp Neurol, Vol.454, No.2, (Dec 9 2002), pp. 200-211, ISSN 0021-9967 (Print) 0021-9967 (Linking)

Robinson, D.; Anders, K.; Cardozo, L.; Bidmead, J.; Toozs-Hobson, P. \& Khullar, V. (2002). Can ultrasound replace ambulatory urodynamics when investigating women with irritative urinary symptoms? BJOG, Vol.109, No.2, (Feb 2002), pp. 145-148, ISSN 1470-0328 (Print) 1470-0328 (Linking)

Schaub, S.; Wilkins, J.; Weiler, T.; Sangster, K.; Rush, D. \& Nickerson, P. (2004). Urine protein profiling with surface-enhanced laser-desorption/ionization time-of-flight mass spectrometry. Kidney Int, Vol.65, No.1, (Jan 2004), pp. 323-332, ISSN 0085-2538 (Print) 0085-2538 (Linking)

Schnegelsberg, B.; Sun, T.T.; Cain, G.; Bhattacharya, A.; Nunn, P.A.; Ford, A.P.; Vizzard, M.A. \& Cockayne, D.A. (2010). Overexpression of NGF in mouse urothelium leads to neuronal hyperinnervation, pelvic sensitivity, and changes in urinary bladder function. Am J Physiol Regul Integr Comp Physiol, Vol.298, No.3, (Mar 2010), pp. R534-547, ISSN 1522-1490 (Electronic) 0363-6119 (Linking)

Sexton, C.C.; Coyne, K.S.; Kopp, Z.S.; Irwin, D.E.; Milsom, I.; Aiyer, L.P.; Tubaro, A.; Chapple, C.R. \& Wein, A.J. (2009a). The overlap of storage, voiding and postmicturition symptoms and implications for treatment seeking in the USA, UK and Sweden: EpiLUTS. BJU Int, Vol.103 Suppl 3, (Apr 2009a), pp. 12-23, ISSN 1464410X (Electronic) 1464-4096 (Linking)

Sexton, C.C.; Coyne, K.S.; Vats, V.; Kopp, Z.S.; Irwin, D.E. \& Wagner, T.H. (2009b). Impact of overactive bladder on work productivity in the United States: results from EpiLUTS. Am J Manag Care, Vol.15, No.4 Suppl, (Mar 2009b), pp. S98-S107, ISSN 1936-2692 (Electronic) 1088-0224 (Linking)

Starkman, J.S. \& Dmochowski, R.R. (2008). Urgency assessment in the evaluation of overactive bladder (OAB). Neurourol Urodyn, Vol.27, No.1, (2008), pp. 13-21, ISSN 0733-2467 (Print) 0733-2467 (Linking) 
Steers, W.D.; Kolbeck, S.; Creedon, D. \& Tuttle, J.B. (1991). Nerve growth factor in the urinary bladder of the adult regulates neuronal form and function. J Clin Invest, Vol.88, No.5, (Nov 1991), pp. 1709-1715, ISSN 0021-9738 (Print) 0021-9738 (Linking)

Steers, W.D.; Creedon, D.J. \& Tuttle, J.B. (1996). Immunity to nerve growth factor prevents afferent plasticity following urinary bladder hypertrophy. J Urol, Vol.155, No.1, (Jan 1996), pp. 379-385, ISSN 0022-5347 (Print) 0022-5347 (Linking)

Steers, W.D. \& Tuttle, J.B. (2006). Mechanisms of Disease: the role of nerve growth factor in the pathophysiology of bladder disorders. Nat Clin Pract Urol, Vol.3, No.2, (Feb 2006), pp. 101-110, ISSN 1743-4270 (Print)

Thompson, S.W.; Bennett, D.L.; Kerr, B.J.; Bradbury, E.J. \& McMahon, S.B. (1999). Brainderived neurotrophic factor is an endogenous modulator of nociceptive responses in the spinal cord. Proc Natl Acad Sci U S A, Vol.96, No.14, (Jul 6 1999), pp. 77147718, ISSN 0027-8424 (Print) 0027-8424 (Linking)

Thongboonkerd, V. (2007). Practical points in urinary proteomics. J Proteome Res, Vol.6, No.10, (Oct 2007), pp. 3881-3890, ISSN 1535-3893 (Print) 1535-3893 (Linking)

Tillett, W.S. \& Francis, T. (1930). Serological Reactions in Pneumonia with a Non-Protein Somatic Fraction of Pneumococcus. J Exp Med, Vol.52, No.4, (Sep 30 1930), pp. 561571, ISSN 0022-1007 (Print) 0022-1007 (Linking)

Tramontana, M.; Catalioto, R.M.; Lecci, A. \& Maggi, C.A. (2000). Role of prostanoids in the contraction induced by a tachykinin NK2 receptor agonist in the hamster urinary bladder. Naunyn Schmiedebergs Arch Pharmacol, Vol.361, No.4, (Apr 2000), pp. $452-$ 459, ISSN 0028-1298 (Print) 0028-1298 (Linking)

Tyagi, P.; Barclay, D.; Zamora, R.; Yoshimura, N.; Peters, K.; Vodovotz, Y. \& Chancellor, M. (2010). Urine cytokines suggest an inflammatory response in the overactive bladder: a pilot study. Int Urol Nephrol, Vol.42, No.3, (Sep 2010), pp. 629-635, ISSN 1573-2584 (Electronic) 0301-1623 (Linking)

van Waalwijk van Doorn, E.S.; Ambergen, A.W. \& Janknegt, R.A. (1997). Detrusor activity index: quantification of detrusor overactivity by ambulatory monitoring. J Urol, Vol.157, No.2, (Feb 1997), pp. 596-599, ISSN 0022-5347 (Print) 0022-5347 (Linking)

Vizzard, M.A. (2000). Changes in urinary bladder neurotrophic factor mRNA and NGF protein following urinary bladder dysfunction. Exp Neurol, Vol.161, No.1, (Jan 2000), pp. 273-284, ISSN 0014-4886 (Print) 0014-4886 (Linking)

Yokoyama, O.; Miwa, Y.; Oyama, N.; Aoki, Y.; Ito, H. \& Akino, H. (2007). Antimuscarinic drug inhibits detrusor overactivity induced by topical application of prostaglandin E2 to the urethra with a decrease in urethral pressure. J Urol, Vol.178, No.5, (Nov 2007), pp. 2208-2212, ISSN 0022-5347 (Print) 0022-5347 (Linking)

Yoshimura, N.; Bennett, N.E.; Hayashi, Y.; Ogawa, T.; Nishizawa, O.; Chancellor, M.B.; de Groat, W.C. \& Seki, S. (2006). Bladder overactivity and hyperexcitability of bladder afferent neurons after intrathecal delivery of nerve growth factor in rats. J Neurosci, Vol.26, No.42, (Oct 18 2006), pp. 10847-10855, ISSN 1529-2401 (Electronic) 0270-6474 (Linking)

Zvara, P. \& Vizzard, M.A. (2007). Exogenous overexpression of nerve growth factor in the urinary bladder produces bladder overactivity and altered micturition circuitry in the lumbosacral spinal cord. BMC Physiol, Vol.7, (2007), pp. 9, ISSN 1472-6793 (Electronic) 1472-6793 (Linking) 


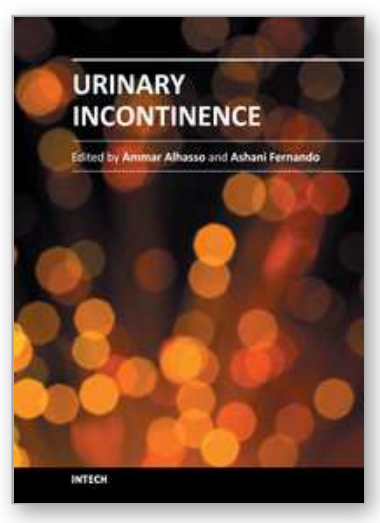

\author{
Urinary Incontinence \\ Edited by Mr. Ammar Alhasso
}

ISBN 978-953-51-0484-1

Hard cover, 324 pages

Publisher InTech

Published online 04, April, 2012

Published in print edition April, 2012

Management strategies are framed within a multidisciplinary team structure and as such a range of specialists ranging from psychologists, specialist nurses, gynaecologists and urologists author the chapters. There are some novel methods outlined by the authors with their clinical application and utility described in detail, along with exhaustive research on epidemiology, which is particularly relevant in planning for the future.

\title{
How to reference
}

In order to correctly reference this scholarly work, feel free to copy and paste the following:

Célia Duarte Cruz, Tiago Antunes Lopes, Carlos Silva and Francisco Cruz (2012). Biomarkers in the Overactive Bladder Syndrome, Urinary Incontinence, Mr. Ammar Alhasso (Ed.), ISBN: 978-953-51-0484-1, InTech, Available from: http://www.intechopen.com/books/urinary-incontinence/biomarkers-in-the-overactivebladder-syndrome

\section{INTECH}

open science | open minds

\author{
InTech Europe \\ University Campus STeP Ri \\ Slavka Krautzeka 83/A \\ 51000 Rijeka, Croatia \\ Phone: +385 (51) 770447 \\ Fax: +385 (51) 686166 \\ www.intechopen.com
}

\author{
InTech China \\ Unit 405, Office Block, Hotel Equatorial Shanghai \\ No.65, Yan An Road (West), Shanghai, 200040, China \\ 中国上海市延安西路65号上海国际贵都大饭店办公楼405单元 \\ Phone: +86-21-62489820 \\ Fax: $+86-21-62489821$
}


(C) 2012 The Author(s). Licensee IntechOpen. This is an open access article distributed under the terms of the Creative Commons Attribution 3.0 License, which permits unrestricted use, distribution, and reproduction in any medium, provided the original work is properly cited. 